\title{
Photoelectrochemical Studies on CdS/Poly Ethyl-Aniline Interfaces
}

\author{
Kasem K. Kasem ${ }^{1} \&$ Aubrey Finley ${ }^{1}$ \\ ${ }^{1}$ School of Sciences, Indiana University Kokomo, Kokomo, USA \\ Correspondence: Kasem K. Kasem, School of Sciences, Indiana University Kokomo, Kokomo, IN, USA. Tel: \\ 1-765-455-9245. E-mail: kkasem@iuk.edu
}

Received: April 10, 2013 Accepted: May 28, 2013 Online Published: July 23, 2013

doi:10.5539/ijc.v5n3p76

URL: http://dx.doi.org/10.5539/ijc.v5n3p76

\begin{abstract}
An inorganic/organic/interface (IOI) consisting of CdS/poly ethyl aniline (PEA) assemblies was subjected to photoelectrochemical studies in nanoparticle suspensions and in thin solid film forms. The effects that PEA modifiers have on the photoelectrochemical behavior of the IOI were investigated using $\left[\mathrm{Fe}(\mathrm{CN})_{6}\right]^{4-}$ as a photoactive hydrated electron donor agent. Results show that the adsorption process of $\left[\mathrm{Fe}(\mathrm{CN})_{6}\right]^{3-}$ (the photolysis product) controls the photoactivity outcome of IOI assemblies. CdS/PEA shows lower heterogeneous photochemical response than native $\mathrm{CdS}$. Native $\mathrm{CdS}$ amorphous nanoparticles adsorb more $\left[\mathrm{Fe}(\mathrm{CN})_{6}\right]^{3-}$ with a very steady adsorption/desorption process than the CdS/PEA. The interface activities were explained by analyzing the IOI junction's properties such as electron affinity, work function and hole/electrons barrier heights. The lower hole barrier height versus electron barrier height suggests that charge injection is mediated at the IOI interface through hole transfer. The aqueous nano systems retained moderate stability as indicated by the reproducibility of their photocatalytic activities. Both $\left[\mathrm{Fe}(\mathrm{CN})_{6}\right]^{4-}$ and PEA contributed to the stability of native CdS surfaces.
\end{abstract}

Keywords: interface, photolysis, suspensions, nanoparticles

\section{Introduction}

Assemblies consisting of inorganic-organic interfaces (IOI) and organic-inorganic interfaces (OII) that have high photoconversion efficiency and are resistant to photocorrosion resistance have been the focus of attention of several investigations in the field of solar energy. Such assemblies include semiconductors in the form of thin filmelectrodes or colloidal systems that might be used in solid or liquid photovoltaic cells (Heera \& Cindrella, 2011; Mahesh \& Arumugam, 2011; Hahlin et al., 2010; Blumstengel et al., 2008; Adams, 2003; Thomas \& Kamat, 2003; Shipway, Katz, \& Willner, 2000; Van Hutten, Krasnikov, \& Hadziioannou, 2001; Kamat, 2002; Cahen et al., 2000). Other examples include metal chalcogenides modified with polyaniline, polypayrol, or other organic semiconductors to name but a few were studied (Kasem, Menges, \& Jones, 2009; Zhang et al., 2008; Graetzel, 2001; Kasem \& Davis, 2008; Kohtani, Kudo, \& Sakata, 1993; Vogel, Hoyer, \& Weller, 1994; Plass et al., 2002; Peter et al., 2003; Liu \& Kamat, 1993). In these studies low conversion efficiencies were reported. Ordered assemblies of narrow band gap semiconductor nanostructures, can be convenient systems to harvest visible light energy. Metal/chalcogenide/oxide semiconductors absorb only solar radiation that matches their band gaps. However, the spectrum adsorption spectra can be widened if the surfaces of the metal sulfides are modified with agent/s that can absorb UV. Many conjugated organic semiconductors absorb UV radiations and then re-emit radiations at longer wave lengths. If an inorganic semiconductor absorbs photons emitted from an adsorbed organic agent, then such an IOI assembly possesses a widened solar radiation absorption range.

Modified CdS with poly Ru vinyl bi-pyridine, was investigated (Kasem, 1999a, 1999b) in the form of thin solid films. Thin films generally offer very limited surface area, which consequently limits the amount of radiation that can be absorbed. The reported poor resistance to photocorrosion (Michikazu et al., 1998; Tatarets et al., 2006) adds another disadvantage to using macrostructures such as thin solid films.

In this paper, we investigate the effects of Poly ethyl aniline as surface modifiers on the activities of $\mathrm{CdS}$ nanoparticles during the photolysis of their aqueous suspensions for hydrogen production. The photocurrent and the amount of hydrogen produced during the photolysis process is used to drive conclusions about the type of magnitude of the effect of these modifiers. Special emphases is given to their effectiveness for harvesting UV-VIS radiation when integrated with CdS particles are into IOI. 


\section{Experimental}

\subsection{Reagents}

Disodium monohydrogen phosphate, potassium ferrocyanides, poly ethyl aniline, chitosan, DMSO, and ethanol were purchased from Aldrich. All reagents used in this study were of analytical grade. All of the solutions were prepared using deionized water, unless otherwise stated. $\mathrm{CdS} / \mathrm{CdS} / \mathrm{PEA}$ was in the form of either nanoparticles or thin solid films.

\subsection{Preparation of $C d S / P E A /$ Interface}

\subsubsection{Colloidal Suspensions of the Cds/PEA}

These samples wereinterface were prepared as reported in (Lee et al., 2009): briefly CdS nanoparticles ( $0.05 \mathrm{~g})$ were suspended in a in $100 \mathrm{ml}$ of 1:1 DMSO/ethanol mixed solvent solution of PEA $(0.05 \mathrm{~g})$. The mixture was subject to a 10 minute sonication followed by stirring for 1hour to allow maximum adsorption of PEA on the $\mathrm{CdS}$ nanoparticles. The excess PEA was removed by centrifuge. The CdS/PEA residue was rinsed with deionized water several times and allowed to dry at $120^{\circ} \mathrm{C}$ for 2 hours. For photolysis experiments, $20 \mathrm{mg}$ of either Cd Sot $\mathrm{CdS} / \mathrm{PEA}$ were suspended in $100 \mathrm{ml}$ of aqueous $0.2 \mathrm{M}$ phosphate buffer ( $\mathrm{pH} 6)$.

\subsubsection{Deposition of Thin Solid Films}

Electrodes of thin solid films of CdS particles modified with PEA prepared as described in 1, were suspended in a chitosan solution. The suspension was homogenously spread over an FTO (Fluorine doped Tin Oxide) slide $(12.5 \times 75 \mathrm{~mm})$ and driedat $120^{\circ} \mathrm{C}$ for 6 hours (Diagram 1$)$.

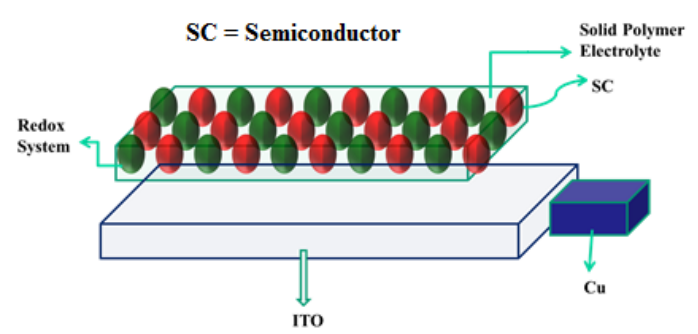

Diagram 1. FTO Modified with PEA immobilized in chitosan

\subsection{Instrumentation}

All electrochemical experiments were carried out using a conventional three electrode cell consisting of a Pt wire as a counter electrode, a $\mathrm{Ag} / \mathrm{AgCl}$ as a reference electrode, and Pt gauze as an electron collector. A BAS 100W electrochemical analyzer (Bioanalytical Co.) was used to perform the electrochemical studies. Steady state reflectance spectra were performed using Shimadzu UV-2101 PC. Irradiation was performed with a solar simulator 300 watt xenon lamp (Newport) with an IR filter.

\subsection{Photolysis Cell}

As illustrated, the electrolysis cell (Diagram 2) was a one-compartment Pyrex cell with a quartz window facing the irradiation source (Kasem \& Zia, 1012). The working electrode, a $10.0 \mathrm{~cm}^{2}$ platinum gauze cylinder, had a solution volume of $100 \mathrm{~mL}$. Suspensions $(20 \mathrm{mg}$ of either $\mathrm{CdS}$ or CdS/PEA/100 ml of aqueous phosphate buffer at $\mathrm{pH}$ 6) were stirred with a magnetic stirrer during the measurements. The $\mathrm{pH}$ was fixed at 6 because below this value formation of $\mathrm{Fe}\left[\mathrm{Fe}(\mathrm{CN})_{6}\right]$ was observed, above $\mathrm{pH} 6$ the photolysis of $\left[\mathrm{Fe}(\mathrm{CN})_{6}\right]^{4-}$ was very slow. $\mathrm{AAg} / \mathrm{AgCl} / \mathrm{Cl}^{-}$reference electrode was also fitted into this compartment. A $10-\mathrm{cm}^{2}$ platinum counter electrode was housed in a glass cylinder sealed in one end with a fine porosity glass frit. 


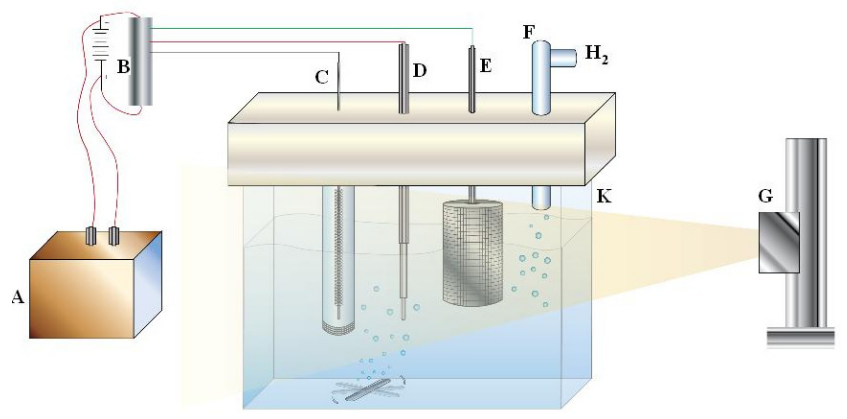

Diagram 2. Diagrams of photolysis cell: $\mathrm{A}=$ Photovoltaic generator, $\mathrm{B}=$ Light powered Potentiostate, $\mathrm{C}=$ Counter electrode, $\mathrm{D}=$ reference electrode, $\mathrm{E}=$ Collector electrode (working electrode), $\mathrm{F}=$ gas outlet, $\mathrm{G}=$ Solar simulator and $\mathrm{K}=$ Cell glass body

Photolysis of $\left[\mathrm{Fe}(\mathrm{CN})_{6}\right]^{4-}$ will generate hydrated electrons and $\left[\mathrm{Fe}(\mathrm{CN})_{6}\right]^{3-}$. The potential of the working electrode potential was fixed at $100 \mathrm{mV}$ more negative than the reduction potential of $\left[\mathrm{Fe}(\mathrm{CN})_{6}\right]^{3-}$ to guarantee full reduction of ferrocyanide. The current due to the reduction of $\left[\mathrm{Fe}(\mathrm{CN})_{6}\right]^{3-}$ collected by the working electrode during the photolysis process is a measure of photocurrent. The measured photocurrent was normalized assuming that two photons were absorbed for every one hydrogen molecule, and was used to calculate the number of moles of hydrogen generated per square meter per hour of illumination.

\section{Results and Discussions}

\subsection{Electrochemical Behavior of PEA}

The potential of the FTO/PEA electrode was potential in $0.5 \mathrm{M} \mathrm{H}_{2} \mathrm{SO}_{4}$ was cycled between -0.5 to $1.5 \mathrm{~V}$ vs $\mathrm{Ag} / \mathrm{AgCl}$. The results are displayed in Figure 1. It can be noticed that more than one redox systems is shown in this CV. The value of the first onset oxidation potential $\mathrm{E}_{\text {ox }}$ of PEA can be detected at $0.15 \mathrm{~V}$ vs. $\mathrm{Ag} / \mathrm{AgCl}$. This value will be used to calculate the Ionization potential of the PEA (Roman et al., 1998). The multi redox potential was also observed in previously reported work (Schemid et al., 2000).

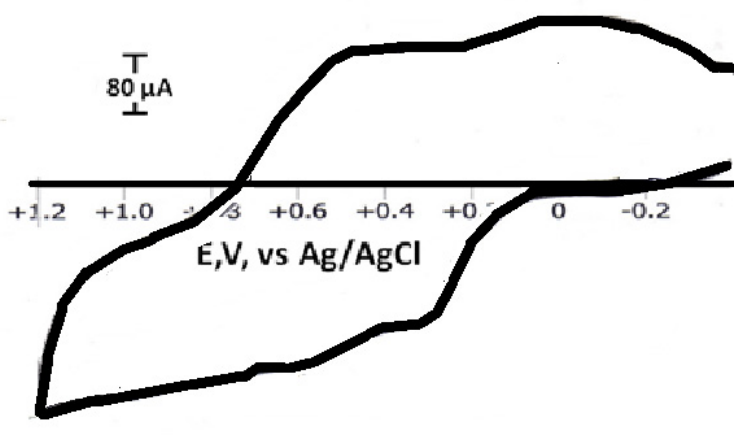

Figure 1. $\mathrm{CV}$ of FTO/PEA electrode in $0.5 \mathrm{M} \mathrm{H}_{2} \mathrm{SO}_{4}$ Scan rate $50 \mathrm{mV} / \mathrm{sec}$

\subsection{Absorption Spectra of PEA}

Absorption spectra of PEA were previously studied (Schemid et al., 2000) under varying potential. Such studies indicated that the redox process at $\approx 0.20 \mathrm{~V}$ is associated with chromophore groups absorbing at ca. 420 and 700 $\mathrm{nm}$; while the further oxidation that takes place at potentials greater than $0.3 \mathrm{~V}$ can be associated with groups absorbing at intermediate wavelengths such as 520 and $620 \mathrm{~nm}$. This is to assume that PEA has more than one chromophore absorbing in the visible spectral region. The fact that PEA's first absorption peak is at $\approx 420 \mathrm{~nm}$ indicates that the corresponding band gap of PEA is $2.95 \mathrm{eV}$. As the PEA used in this study was emeraldine base type, a range of absorption does take place between 520-620 nm. 
This is an indication of the energy intervals with high density states that represent HOMO (higher occupied molecular orbitals) and LUMO (lower unoccupied molecular orbitals). Photon absorption depends on dopants within the polymer matrix's that affects the charge injection. The absorbed photons are consumed in generating charge carriers, probably by an extrinsic mechanism that is based on photon-induced charge transfer separation/transfer processes.

\subsection{Absorption Spectra of CdS/PEA Nanoparticles}

Steady state reflectance spectra of the CdS/PEA nano-particles are shown in Figure 2. Two regions of absorption are apparent, one within the range $400 \mathrm{up}$ to $\approx 540 \mathrm{~nm}$ and moderate absorption above $600 \mathrm{~nm}$. The first absorption region is corresponding to both $\mathrm{CdS}$ and an oxidized PEA. The second absorption region corresponds to the further absorbing chromophores that PEA may have after its structure is altered by the redox process. Illuminated IOI of the CdS/PEA assembly causes a change in the electrical field that create potential differences. The large absorption in the region of the approximate values of the band gaps derived from this figure are listed in Table 1. Figure $3 \mathrm{~A}$ and B were generated after further analysis of the spectra in Figure 2 following the method of previous studies (Robert et al., 1995). Figure 3A, displays three lines intercepting energy axes at a, b, and c, which indicates multiple gaps (indirect band within the CdS/PEA assemblies. On the other hand Figure 3B indication of the direct band gap of the same assemblies.

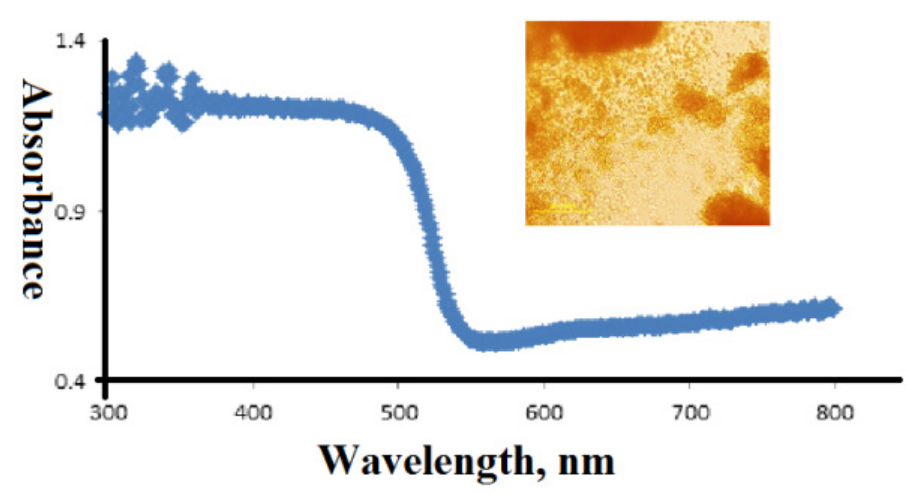

Figure 2. Steady state reflectance spectra for CdS/PEA nanoparticles. Inset (Microscopic image of the CdS/PEA nanoparticles suspension
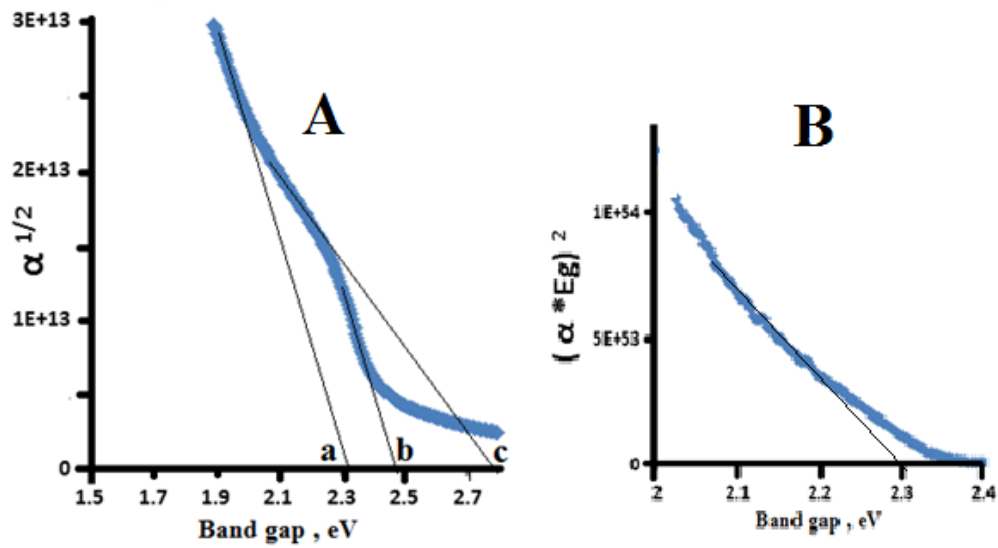

Figure 3. Tauc plots for indirect and direct band gapCdS/PEA: A) indirect (intercepts at a, b and c indicates several indirect band gaps B) direct 
Table 1. Photo-electrochemical data at CdS/ PEA interface

\begin{tabular}{lll}
\hline \multicolumn{1}{c}{ Property, eV } & CdS & \multicolumn{1}{c}{$\boldsymbol{P E A}$} \\
\hline Onset Oxidation potential (vs, $\mathrm{Ag} / \mathrm{AgCl})$ & & $0.25 \mathrm{~V}$, \\
Measured band gap, Ea & 2.2 & 2.5 \\
Ionization potential, IP & & $4.65 \mathrm{eV}$ \\
Work function, $\boldsymbol{\Phi}$ & $\mathbf{4 . 6 5}$ & \\
Electron Affinity, EA & 4.45 & $1.85 \mathrm{eV}$ \\
Holes' Barrier Height, $\boldsymbol{\varphi}_{h}$ at IOI * & & 0.0 \\
Electrons 'Barrier Height, $\boldsymbol{\varphi}_{e}$ at IOI & & 2.15 \\
\hline
\end{tabular}

\subsection{Energy Map of PEA}

In order to draw the energy map of PEA along with the band gap $\left(\mathrm{E}_{\mathrm{g}}\right)$, parameters such as IP and EA are required. Furthermore, these parameters are needed to explain the electrical and optical properties of the film. Relating electrochemical data, such as the onset oxidation potential $\left(E_{\text {ox }}^{\prime}\right)$, the onset reduction potential $\left(E_{\text {Red }}^{\prime}\right)$, and the band gap leads to an understanding of the integrated energy diagram of the film. Onset potentials can be estimated from the intersection of the two tangents drawn at the rising oxidation current curve and the background current curve in the CV using the following formula (Roman et al., 1998):

$$
\mathrm{E}_{\mathrm{ox}}=\mathrm{E}_{\text {ox }}^{\prime}+\mathrm{E}_{\text {reference electrode }} \approx \mathrm{E}_{\text {vac }}+4.6 \mathrm{eV}
$$

Because $\mathrm{Ag} / \mathrm{AgCl}$ was used as a reference electrode $\left(\mathrm{E}^{0}=0.197 \mathrm{~V}\right.$ vs $\left.\mathrm{NHE}\right)$, and $\mathrm{E}_{\text {vac }} \approx 0$, the above equation can be rewritten as:

$$
\mathrm{IP}=\mathrm{E}_{\mathrm{ox}}^{\prime}+4.4 \mathrm{eV}
$$

Where IP isIonization potential. Considering the energy gap between HOMO (valence band) and LUMO (conduction band) to be the band gap (Eg), and the energy gap between the LUMO and vacuum to be the electron affinity (EA), we can rewrite the following equation:

$$
\mathrm{IP}=\mathrm{EA}+\mathrm{Eg}
$$

By integrating the data in Figure 1, Figure 3 and in Equations 1-3, a list of photo-electrochemical data for CdS and PEA were deduced, recorded in Table 1. The fact that the electron barrier height is large $(2.5 \mathrm{eV})$ and much greater than the hole barrier height may indicate that charge injection is mediated at the IOI interface through hole transfer.

\subsection{Photoelectrochemical Studies on PEA Thin Films}

\subsubsection{Photoelectrochemical Behavior of CdS/PEA Aqueous Suspensions}

Theory:

Photolysis of $[\mathrm{Fe}(\mathrm{CN}) 6]^{4-}$ generates hydrated electrons $\left(\mathrm{e}_{\mathrm{aq}}{ }^{-}\right)$. The following equations describe the important role that these electrons play in photo dissociation of water through these reactions:

$$
\begin{aligned}
{\left[\mathrm{Fe}(\mathrm{CN})_{6}\right]^{4-}+\mathbf{h v} } & =\left[\mathrm{Fe}(\mathrm{CN})_{6}\right]^{3-}+\mathrm{e}_{\mathrm{aq}^{-}} \\
\mathrm{e}_{\mathrm{aq}^{-}}+\mathrm{e}_{\mathrm{aq}^{-}}= & \mathrm{H}_{2}+2 \mathrm{OH}^{-}
\end{aligned}
$$

If the reaction in Equation 4 is reversed by reducing $\left[\mathrm{Fe}(\mathrm{CN})_{6}\right]^{3-}$ back to $\left[\mathrm{Fe}(\mathrm{CN})_{6}\right]^{4-}$, generation of hydrated electrons will continue. Reversing reaction 1 is possible by using a SC (Semiconductor)that emits electrons upon illumination according to the following reaction:

$$
\left[\mathrm{Fe}(\mathrm{CN})_{6}\right]^{3-}+\mathbf{h} \boldsymbol{v}+(\mathbf{e} / \mathbf{h})=\left[\mathrm{Fe}(\mathrm{CN})_{6}\right]^{4-}+\mathrm{h}(+\mathrm{ve} \text { center })
$$

Where $(\mathrm{e} / \mathrm{h})$ is an excited $\mathrm{SC}$, however, production of $\mathrm{H}_{2}$ in the presence of $\mathrm{SC}$ particles can also be possible by a different route. The $\mathrm{H}_{2} \mathrm{PO}_{4}{ }_{4}$ act as a hole scavenger (Mohammad et al., 1990); and the following reaction can take place:

$$
\mathrm{H}_{2} \mathrm{PO}_{4}^{-}+\mathrm{h}\left(\text { from VB) }=\mathrm{H}_{2} \mathrm{PO}_{4}{ }^{*}\right.
$$

The adsorbed $\left[\mathrm{Fe}(\mathrm{CN})_{6}\right]^{3-}$ on the particle capture electrons from $\mathrm{CB}$ (Conduction band) according to this reaction:

$$
\left[\mathrm{Fe}(\mathrm{CN})_{6}\right]^{3-}{ }_{\text {(ads. })}+(\text { e from CB })+\mathrm{H}_{3} \mathrm{O}^{+}=\left[\mathrm{Fe}(\mathrm{CN})_{6}\right]^{3-}+1 / 2 \mathrm{H}_{2}
$$


In the presence of SC, the recorded collector electrodes reduction current will be less than that recorded in suspension-free $10 \mathrm{mM}\left[\mathrm{Fe}(\mathrm{CN})_{6}\right]^{4-}$ (hereafter described reference system). This decrease is due to either reaction 6 or 7 or both. Reaction 6 causes photo-reduction of $\left[\mathrm{Fe}(\mathrm{CN})_{6}\right]^{3-}$, so less of it can be reduced electrochemically at the collector electrode. On the other hand the adsorption of $\left[\mathrm{Fe}(\mathrm{CN})_{6}\right]^{4-}$ on the particle surface reduces the amount of $\left[\mathrm{Fe}(\mathrm{CN})_{6}\right]^{3-}$ produced by reaction 4 and consequently less electrochemical reduction current will be recorded for the collector electrode.

The photoreduction of $\left[\mathrm{Fe}(\mathrm{CN})_{6}\right]^{3-}$ caused by $\mathrm{SC}$ is calculated as follows:

$$
\text { Photoreduction current: } I_{\text {photored. }}=I_{\text {red }} \text { (in reference system) - } I_{\text {red }} \text { (in presence of SC) }
$$

The greater the $\mathrm{I}_{\text {photored, }}$ the better the $\mathrm{SC}$ is for the photolysis process.

Aqueous suspensions of pure and surface-modified CdS in $0.2 \mathrm{M}$ phosphate buffer at $\mathrm{pH} 6$ containing $20 \mathrm{mM}$ $\mathrm{K}_{4}\left[\mathrm{Fe}(\mathrm{CN})_{6}\right]$ were subject to the photolysis process. The potential of the Pt collector electrode was kept constant at $0.000 \mathrm{~V}$ vs $\mathrm{Ag} / \mathrm{AgCl}$. The results are displayed in Figures 4, 5 and 6 . The recorded photocurrent in these figures is due to electrochemical reduction of $\mathrm{K}_{3}\left[\mathrm{Fe}(\mathrm{CN})_{6}\right]$. In the presence of illuminated native or surface-modified $\mathrm{CdS}$, reduction of $\left[\mathrm{Fe}(\mathrm{CN})_{6}\right]^{3-}$ can take place by an electrochemical and/or by a photochemical process, but the collector electrode records only the electrochemical process. Figure 4 shows that the recorded electrochemical reduction current in homogeneous solutions of $\left[\mathrm{Fe}(\mathrm{CN})_{6}\right]^{4-}$ (Figure 4 trace A) is greater than that recorded for heterogeneous solutions in the presence of native CdS (Figure 4 trace $\mathrm{B}$ ), is also greater than that of PEA (Figure 5 trace B) or that of CdS/PEA (Figure 5 trace C). Furthermore, Figure 5 shows that although CdS/PEA did not increase the photoreduction process more than CdS (Figure 5B and C), the plateau of peak 5C is wider than that at 5B. This is an indication of the stability of the CdS/PEA particle surface area.

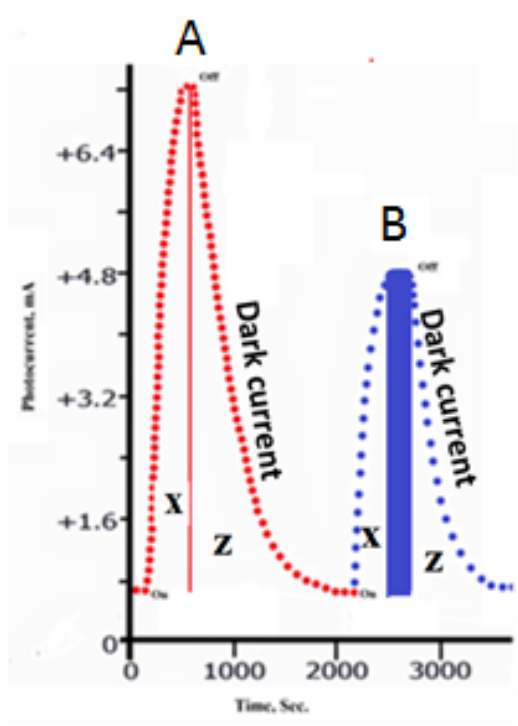

Figure 4. Photolysis of aqueous suspensions of studies IOI containing $0.2 \mathrm{M}$ Phosphate buffers and $10 \mathrm{mM}$ of $\left[\mathrm{Fe}(\mathrm{CN})_{6}\right]^{4-}$ A- Ref. $\left(10 \mathrm{mM}\right.$ of $\left.\left[\mathrm{Fe}(\mathrm{CN})_{6}\right]^{4-}\right)$, B- Ref. + CdS/PEA 


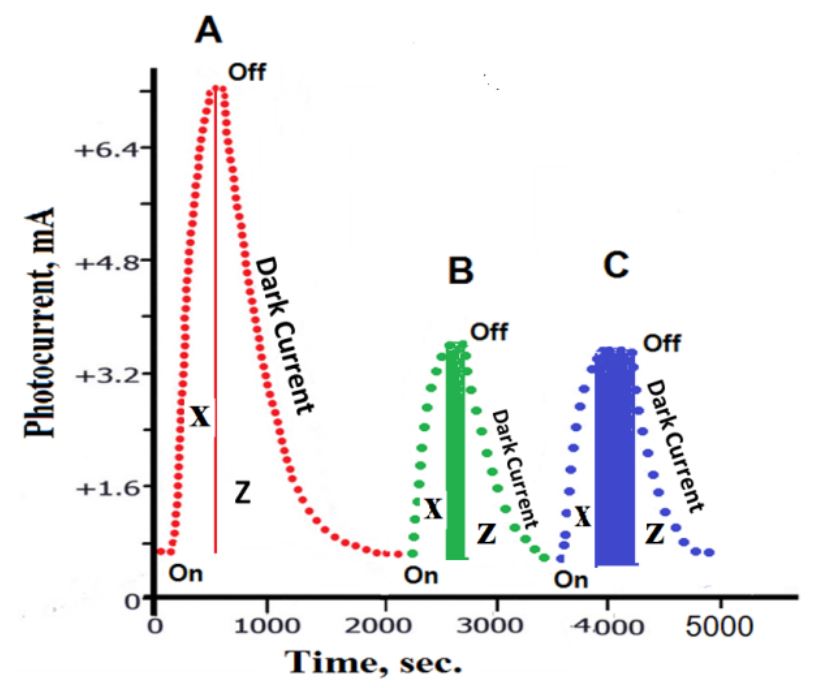

Figure 5. Photolysis of aqueous suspensions of CdS/PEA containing $0.2 \mathrm{M}$ Phosphate buffers and $10 \mathrm{mM}$ of $\left[\mathrm{Fe}(\mathrm{CN})_{6}\right]^{4-}$, A-Ref. $\left(10 \mathrm{mM}\right.$ of $\left.\left[\mathrm{Fe}(\mathrm{CN})_{6}\right]^{4-}\right)$, B-Ref. + PEA, C-B. + CdS

The smaller electrochemical reduction current in the heterogeneous system than that in homogenous system can be explained as follows. When SC nanoparticles are added to $\left[\mathrm{Fe}(\mathrm{CN})_{6}\right]^{4-}$ solutions, the following processes takes place:

$$
\mathrm{M}^{+\mathrm{Z}} \text { (solubility equilibrium ) }+\left[\mathrm{Fe}(\mathrm{CN})_{6}\right]^{4-}=\mathrm{M}\left\{\left[\mathrm{Fe}(\mathrm{CN})_{6}\right]^{4-\mathrm{Z}}\right\}_{(\mathrm{s})}
$$

$\mathrm{M}\left\{\left[\mathrm{Fe}(\mathrm{CN})_{6}\right]^{4-\mathrm{Z}}\right\}(\mathrm{s})$ will stabilize (Rubin et al., 1987; Tennakone, 1983) the surface against photo degradation. Calculations based on particle size (100-nm radius), $\mathrm{CdS}$, and the stoichiometry of reaction 5 indicated that the amount of $\left[\mathrm{Fe}(\mathrm{CN})_{6}\right]^{4-}$ consumed in reaction 5 is less that $0.06 \%$ of its the original concentration of $20.0 \mathrm{mM} / \mathrm{L}$.

Adsorption of $\left[\mathrm{Fe}(\mathrm{CN})_{6}\right]^{3-}$ (product of reaction 1) on the surface of nanoparticles (Desilvestro et al., 1988; Cheng et al., 2000; Pharr \& Griffiths, 1997). Adsorption decreases the amount of $\left[\mathrm{Fe}(\mathrm{CN})_{6}\right]^{4-}$ oxidized in reaction 1, while adsorption of $\left[\mathrm{Fe}(\mathrm{CN})_{6}\right]^{3-}$ reduces the amount of free $\left[\mathrm{Fe}(\mathrm{CN})_{6}\right]^{3-}$ that can reach the Pt regenerator electrode. In both cases the recorded reduction current will be less than that reported in homogenous system. However, under illumination all of $\left[\mathrm{Fe}(\mathrm{CN})_{6}\right]^{4-}$ will be oxidized to $\left[\mathrm{Fe}(\mathrm{CN})_{6}\right]^{3-}$ and the surface of nanoparticles will be covered only with $\left[\mathrm{Fe}(\mathrm{CN})_{6}\right]^{3-}$. This amount of $\left[\mathrm{Fe}(\mathrm{CN})_{6}\right]^{3-}$ will be identified from now on as $\left\{\left[\mathrm{Fe}(\mathrm{CN})_{6}\right]^{3-}\right\}$ ads. This adsorbed ferricyanide will be photochemically reduced at the nanoparticle surface.

The very small amount of $\left[\mathrm{Fe}(\mathrm{CN})_{6}\right]^{4-}$ consumed in making the insoluble layer $(<0.05 \%)$ suggests that adsorption phenomena are the main factors that can explain why the reduction current recorded by Pt regenerator electrode in the presence of nanoparticles is lower than that in homogenous solution.

The relatively high concentration of $\mathrm{H}_{2} \mathrm{PO}_{4}{ }^{1-}(0.2 \mathrm{M})$ in comparison with $0.02 \mathrm{M}$ concentration of $\left[\mathrm{Fe}(\mathrm{CN})_{6}\right]^{4-}$ causes $\mathrm{H}_{2} \mathrm{PO}_{4}{ }^{1-}$ to be the major adsorbed species on the surface of nanoparticles. The following mechanism is suggested for the photochemical reduction that causes the reversibility of reaction 1 :

Step 1: $\left[\mathrm{Fe}(\mathrm{CN})_{6}\right]^{4-}+\mathrm{h} v=\left[\mathrm{Fe}(\mathrm{CN})_{6}\right]^{3-}+\mathrm{e}_{\mathrm{aq}}$.

Step 2: $\left[\mathrm{Fe}(\mathrm{CN})_{6}\right]^{3-}+\mathrm{SC}$ nanoparticles $\rightarrow\left\{\left[\mathrm{Fe}(\mathrm{CN})_{6}\right]^{3-}\right\}$ ads.

Step 3: $\mathrm{H}_{2} \mathrm{PO}_{4}{ }^{1-}$ acts as hole scavenger and undergoes photo-oxidation to H2PO4* [29] as follows:

$$
\mathrm{SC}(\mathrm{e} / \mathrm{h})+\mathrm{H}_{2} \mathrm{PO}_{4}{ }^{1-}=\mathrm{H}_{2} \mathrm{PO}_{4}{ }^{*}+\mathrm{e} \text { (conduction band) }
$$

Where (e) are electrons in conduction band, $\mathrm{h}=$ hole in valence band. This step is based on the fact that the calculated e- barrier heights $(2.50 \mathrm{eV}$ ) (Lana et al., 2004) for the SCs used in this study is greater than hole barrier heights (Table 1). This suggests that the hole transfer takes place first to oxidize $\mathrm{H}_{2} \mathrm{PO}_{4}{ }^{1-}$ (because of its higher concentration than ferrocyanide anion). That the hole is neutralized first suggests that reduction of ferricyanide follow the hole consummation as step 4 shows:

Step 4: $\left\{\left[\mathrm{Fe}(\mathrm{CN})_{6}\right]^{3-}\right\}$ ads. + e (from CB) $=\left\{\left[\mathrm{Fe}(\mathrm{CN})_{6}\right]^{4-}\right\}$ ads.

Step 5: $\left\{\left[\mathrm{Fe}(\mathrm{CN})_{6}\right]^{4-}\right\}$ ads desorbed to give free $\left\{\left[\mathrm{Fe}(\mathrm{CN})_{6}\right]^{4-}\right\}$ desorb.

Step 6: $\left\{\left[\mathrm{Fe}(\mathrm{CN})_{6}\right]^{4-}\right\}$ desorb photo-oxidized in the homogenous solution to $\left[\mathrm{Fe}(\mathrm{CN})_{6}\right]^{3-}$ and included in repeating 
step 1.

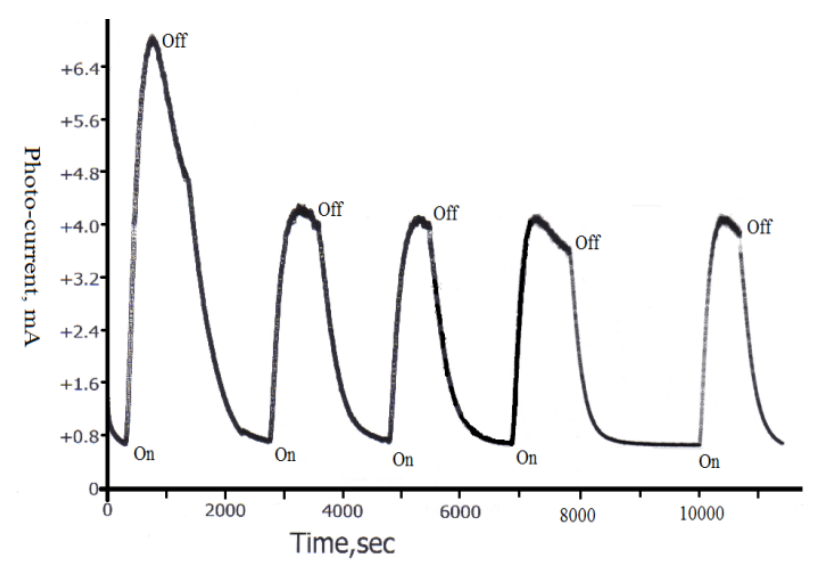

Figure 6. CdS/Poly aniline reproducibility

The portion of $\left[\mathrm{Fe}(\mathrm{CN})_{6}\right]^{3-}$ generated by step 1 and not adsorbed in step 2 reaches the Pt electrode to be reduced back is represented by areas $\mathrm{X}$ in Figures 4 and 5. The difference in area $\mathrm{x}$ in Figure 4A and that in Figure 4B represents the amount of adsorbed $\left[\mathrm{Fe}(\mathrm{CN})_{6}\right]^{3-}$ on the $\mathrm{CdS} / \mathrm{PEA}$ (Figure $4 \mathrm{~B}$ ) nanoparticle surfaces. It can be concluded that areas $\mathrm{x}$ in Figures 4 directly reflect the behavior of Pt generator electrode in the absence of SC interference. A similar discussion can be made about Figure 5. The difference in area $\mathrm{x}$ in Figure 5A and that in Figures $5 \mathrm{~B}$ and $5 \mathrm{C}$ represents the amount of adsorbed $\left[\mathrm{Fe}(\mathrm{CN})_{6}\right]^{3-}$ on the PEA (5B) and on CdS/PEA (5 C) nanoparticle surfaces. The shaded areas in Figures 4 and 5 represent the semiconductor's nanoparticles adsorption/desorption processes. The wider the plateau, the better the enhancement to the photolysis process is, and the more efficient the hydrogen production process. The result listed in Table 2 indicates that the native CdS gives a better rate of hydrogen production than that of PEA or CdS/PEA (IOI). Figure 6 shows reproducible results for the recorded electrochemical reduction current upon using CdS/PEA nanoparticles in the photolysis media.

Table 2. Photolysis of aqueous nanoparticles suspensions in $20 \mathrm{mM}\left[\mathrm{Fe}(\mathrm{CN})_{6}\right]^{4} / 0.20 \mathrm{M}$ Phosphate buffer (pH 6)

\begin{tabular}{ccc}
\hline System & Percentage $(\%)$ & Steady state $\mathbf{H}_{\mathbf{2}}$ production, Mole $^{\mathbf{1}} \cdot \mathbf{m}^{\mathbf{- 2}}$ \\
\hline CdS $100 \%$ & 62.6 & 0.0676 \\
Poly Aniline & 48 & 0.0528 \\
CdS/PolyAniline & 44 & 0.0484 \\
\hline
\end{tabular}

\subsubsection{Electrochemical Behavior of Cds/PEA Thin Solid Film}

Figure 7 is a display of the photocurrent recorded for FTO/CdS/PEA thin solid film (Diagram 1), in I-/I3- at $-0.400 \mathrm{vs} \mathrm{Ag} / \mathrm{AgCl}$. These results indicate approximately the same amount of photocurrent per each trial, however in Figure 6 (trace b), the current drops at longer illumination time. These results are evidence that $\mathrm{CdS} / \mathrm{PEA}$ can be used efficiently in photolysis of aqueous solutions in solid or nanoparticle state. 


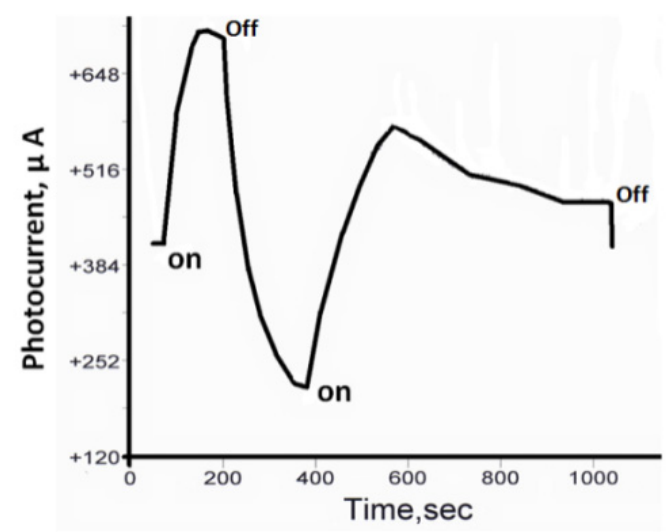

Figure 7. FTO/solid film chitosan $\mathrm{CdS} /(\mathrm{PEA}) / \mathrm{Li}$ salt $/ \mathrm{I}^{-} / \mathrm{I}_{3}{ }^{-} / \mathrm{Ag}$ at $-0.400 \mathrm{vs} \mathrm{Ag} / \mathrm{AgCl}$

\section{Conclusion}

Characterization of the IOI of CdS/PEA as an/p junction is consistent with the EA data listed in Table. Due to the very low hole barrier height in comparison to that of electron barrier height $(2.5 \mathrm{eV})$, the charge injection/transfer mechanism took place through hole transfer. Such hole transfer causes reaction 7 to take place first to consume the hole, while the electrons are used to complete reaction 8. The results displayed in Figure 6 show a reproducible behavior of this IOI assembly. Although, the effect of adding nanoparticles of PEA alone did not significantly increase the photoreduction process over that caused by the combined CdS/PEA (Figure 5B and C), the later shows a steady photoredcution process for longer time of period as indicated by the width of the plateau in Figure 5C.

\section{References}

Adams, D. (2003). Charge Transfer on the Nanoscale. J. Phys. Chem. B, 107, 6668-74. http://dx.doi.org/10.1021/jp0268462

Blumstengel, S., Koch, N., Sadofev, S., Schafer, P., Glowatzki, H., Johnson R. L., ... Henneberger, F. (2008). Room temperature ferromagnetism in $\mathrm{ZnO}$ films due to defects. Applied Physics Letters, 92(19), 193303-06. http://dx.doi.org/10.1063/1.2918089

Cahen, D., Hodes, G., Graetzel, M., Guillemoles, J. F., \& Riess, I. (2000). Nature of Photovoltaic Action in Dye-Sensitized Solar Cells. J. Phys. Chem., 104, 2053-59. http://dx.doi.org/10.1021/jp993187t

Cheng, W. P., Huang, C., \& Chien, Y. C. (2000). Competitive Adsorption of Ferricyanide and Ferrocyanide On $\gamma-\mathrm{Al}_{2} \mathrm{O}_{3}$ Surface. J. Colloid. \& Interface Sci., 224(2), 291-296. http://dx.doi.org/10.1006/jcis.1999.6684

Desilvestro, J., Bons, S., Vrachnqu, E., \& Gratzel, M. (1988). Electrochemical and FTIR Spectroscopic Characterization of ferrocyanide-Modified $\mathrm{TiO}_{2}$ Electrodes Designed for Efficient Photosensitization. $J$. Electroanal. Chem., 234(2), 411-422.

Graetzel, M. (2001). Photoelectrochemical cells. Nature, 414, 338-342. http://dx.doi.org/10.1038/35104607

Hahlin, M., Johansson, E. M., Plogmaker, S., Odelius, M., Hagberg, P. D., Sun, L., ... Rensmo, H. (2010). Electronic and molecular structures of organic dye/ $\mathrm{TiO}_{2}$ interfaces for solar cell applications: a core level photoelectron spectroscopy study. Phys. Chem. Chem. Phys., 12(7), 1507-17. http://dx.doi.org/10.1039/b913548k

Heera, T. R., \& Cindrella, L. (2011). PbS/CoS-Pani composite semiconductor films. Materials Science in Semiconductor Processing, 14(2), 151-156. http://dx.doi.org/10.1016/j.mssp.2011.02.002

Kamat, P. V. (2002). Photophysical, photochemical and photocatalytic aspects of metal nanoparticles. J. Phys. Chem. B, 106, 7729-44. http://dx.doi.org/10.1021/jp0209289

Kasem, K. K. (1999a). Photo-electrochemistry at polymer/semiconductor interface Characterization of surface modified CdS based photovoltaic cells. J. Mat. Science, 34, 5237-5242. http://dx.doi.org/10.1023/A:1004772231981

Kasem, K. K. (1999b). Photo-electrochemistry on stationary surface modified CdSe electrodes. Material Science and Engineering B, 65, 127-134. http://dx.doi.org/10.1016/S0921-5107(99)00218-4

Kasem, K. K., \& Davis, C. (2008). Photoelectrochemical studies on colloidal copper (I) oxide/modified with some 
organic semiconductors: Incentive for use of nanoparticle systems. Bulletin of Materials Science, 31(7), 925-929. http://dx.doi.org/10.1007/s12034-008-0147-5

Kasem, K. K., \& Zia, N. (2012). Photoelectrochemical Studies at CdS/PTTh Nanoparticles Interfaces. Mat. Sci. Appl., 3(10), 719-727.

Kasem, K. K., Menges, S., \& Jones, S. (2009). Photoelectrochemical studies on poly[1-(2-aminophenyl)pyrrole] - Creation of a photoactive inorganic-organic semiconductor interface (IOI). Canadian Journal of Chemistry, 87(8), 1-8. http://dx.doi.org/10.1139/V09-079

Kohtani, S., Kudo, A., \& Sakata, T. (1993). Pectral sensitization of a titania semiconductor electrode by cadmium sulfide microcrystals and its photoelectrochemical properties. Chem. Phys. Lett., 206(1-4), 166-170. http://dx.doi.org/10.1016/0009-2614(93)85535-V

Lee, H. L., Issam, A. M., Belmahi, M., Assouar, M. B., Rinnert, H., \& Alnot, M. (2009). Synthesis and characterizations of bare CdSnanocrystals using chemical precipitation method for photoluminescence application. Journal of Nanomaterials, 914501. http://dx.doi.org/10.1155/2009/914501

Liu, D., \& Kamat, P. V. (1993). Photoelectrochemical behavior of thin cadmium selenide and coupled titania/cadmium selenide semiconductor films. J. Phys. Chem., 97, 10769-73. http://dx.doi.org/10.1021/j100143a041

Mahesh, A. (2011). Photovoltaic performance of $\mathrm{ZnO}$ nanosheets solar cell sensitized with beta-substituted porphyrin. Journal of Nanomaterials, 301873. http://dx.doi.org/10.1155/2011/301873

Michikazu, H., Takeshi, K., Mutsuko, K., Sigeru, I., Kiyoaki, S., Akira, T., ... Kazunari, K. (1998). Cu그 as a photocatalyst for overall water splitting under visible light irradiation. Chem. Commu., 3, 357-358.

Mohammad, A., Low, G. K. C., \& Matthews, R. W. (1990). Effects of common inorganic anions on rates of photocatalytic oxidation of organic carbon over illuminated titanium dioxide. J. Phys. Chem., 94, 6820-25. http://dx.doi.org/10.1021/j100380a051

Peter, L. M., Wijayantha, K. G., Riley, D. J., \& Waggett, J. P. (2003). Band-Edge Tuning in Self-Assembled Layers of $\mathrm{Bi}_{2} \mathrm{~S}_{3}$ Nanoparticles Used To Photosensitize Nanocrystalline $\mathrm{TiO}_{2}$. J. Phys. Chem. B, 107, 8378-81. http://dx.doi.org/10.1021/jp0303341

Pharr, C. M., \& Griffiths, P. R.(1997). Infrared Spectroelectrochemical Analysis of Adsorbed Hexacyanoferrate Species Formed during Potential Cycling in the Ferrocyanide/Ferricyanide Redox Couple. Anal. Chem., 69, 4673-4679. http://dx.doi.org/10.1021/ac9611201

Plass, R., Pelet, S., Krueger, J., Gratzel, M., \& Bach, U.(2002). Quantum Dot Sensitization of Organic-Inorganic Hybrid Solar Cells. J. Phys. Chem. B, 106, 7578-80. http://dx.doi.org/10.1021/jp0204531

Roman, L.S., Hummelgen, I. A., Nart, F. C., Peres, F. C., de Sa, E. L. (1998). Determination of electroaffinity and ionization potential of conjugated polymers via Fowler-Nordheim tunneling measurements: theoretical formulation and application to poly(p-phenylenevinylene. J. Chem. Phys., 105(23), 10614-20. http://dx.doi.org/10.1063/1.472947

Rubin, H., Arent, D., Humphrey, B., \& Bocarsly, A. (1987). Overlayer Formation as a Source of Stability in the N-Type Photoelectrochemical Cell. J. Electrochem. Soc., 134, 93-101. http://dx.doi.org/10.1149/1.2100444

Schemid, A. L., de Torresi, S. I. C., Bassetto, A. N., \& Carlos, I. A. (2000). Structrural, Morphological and Spectroelectrochemical Characterization of Poly(2- ethyl aniline). J. Braz. Chem. Soc., 11(3), $317-323$. http://dx.doi.org/10.1590/S0103-50532000000300020

Shipway, A. N., Katz, E., \& Willner, I. (2000). Nanoparticle arrays on surfaces for electronic, optical, and sensor $\begin{array}{lllll}\text { applications. Chem. } & \text { Phys. } & \text { Chem., } & 1, & 18-52 .\end{array}$ http://dx.doi.org/10.1002/1439-7641(20000804)1:1<18::AID-CPHC18>3.0.CO;2-L

Tatarets, A. L., Fedyunyayeva, I. A., Dyubko, T. S., Povrozin, Y. A., Doroshenko, A, O., Terpetschnig, E. A., \& Patsenker, L. D. (2006). Synthesis of water-soluble, ring-substituted squaraine dyes and their evaluation as fluorescent probes and labels. Analytica Chimica Acta, 214, 570-576. http://dx.doi.org/10.1016/j.aca.2006.04.019

Tennakone, K. (1983). The activation of n-type semiconduction in ferrocyanides and p-type semiconduction in ferricyanides by interstitial water. J. Phys. C: Solid State Phys., $16, \quad$ L1193. http://dx.doi.org/10.1088/0022-3719/16/34/001 
Thomas, K. G., \& Kamat, P. V. (2003). Chromophore-Functionalized Gold Nanoparticles. Acc. Chem. Res., 36(12), 888-898. http://dx.doi.org/10.1021/ar030030h

Van Hutten, P. F., Krasnikov, V. V., \& Hadziioannou, G. (2001). Field-effect mobilities in spin-cast and vacuum-deposited PPV-type pentamers. Synthetic Metals, 122(1), 191-194. http://dx.doi.org/10.1016/S0379-6779(00)01352-7

Van leeuwen, R. A., Hung, C., Kammler, D. R., \& Switzer, J. A. (1995). Optical and Electronic Transport Properties of Electrodeposited Thallium(III) Oxide Films. J. Phys. Chem, 99(41), 15247. http://dx.doi.org/10.1021/j100041a047

Villarreal, T. L., Gómez, R., Neumann-Spallart, M., Alonso-Vante, N., \& Salvador, P. (2004). Semiconductor Photooxidation of Pollutants Dissolved in Water: A Kinetic Model for Distinguishing between Direct and Indirect Interfacial Hole Transfer. I. Photoelectrochemical Experiments with Polycrystalline Anatase Electrodes under Current Doubling and Absence of Recombination. J. Phys. Chem. B, 108(39), 15172-81. http://dx.doi.org/10.1021/jp049447a

Vogel, R., Hoyer, P., \& Weller, H. (1994). Quantum-Sized PbS, CdS, $\mathrm{Ag}_{2} \mathrm{~S}, \mathrm{Sb}_{2} \mathrm{~S}_{3}$, and $\mathrm{Bi}_{2} \mathrm{~S}_{3}$ Particles as Sensitizers for Various Nanoporous Wide-Bandgap Semiconductors. J. Phys. Chem., 98, 3183-87. http://dx.doi.org/10.1021/j100063a022

Zhang, Q., Wu, T., Bu, X., Tran, T., \& Feng, P. (2008). Ion Pair Charge-Transfer Salts Based on Metal Chalcogenide Clusters and Methyl Viologen Cations. Chem. of Mate., 20(13), 4170-72. http://dx.doi.org/10.1021/cm800904d

\section{Copyrights}

Copyright for this article is retained by the author(s), with first publication rights granted to the journal.

This is an open-access article distributed under the terms and conditions of the Creative Commons Attribution license (http://creativecommons.org/licenses/by/3.0/). 